Available online: https://journal.uny.ac.id/index.php/jpa

Jurnal Pendidikan Anak, Volume 9 (1), 2020, 33-39

\title{
Implementasi permainan tradisional dalam pembelajaran anak usia dini sebagai pembentuk karakter bangsa
}

\author{
Banu Setyo Adi, Sudaryanti, Muthmainnah \\ Pendidikan Guru Sekolah Dasar, FIP, Universitas Negeri Yogyakarta \\ Jalan Colombo No 1 Yogyakarta, Indonesia \\ E-mail: banu_adi@uny.ac.id, sudaryanti@uny.ac.id, muthmainnah@uny.ac.id
}

\begin{tabular}{ll}
\hline \hline ARTICLE INFO & ABSTRACT \\
\hline \hline Article & Permainan tradisional memiliki manfaat yang beragam untuk pengembangan \\
history: & anak usia dini, termasuk membentuk karakter anak usia dini. Program pelatihan \\
Received:26-04-2020 & ini bertujuan untuk meningkatkan pemahaman guru tentang cara memodifikasi \\
Revised: $05-05-2020$ & permainan tradisional, kemudian menerapkannya dalam pembelajaran, serta \\
Accepted: $12-05-2020$ & mendiseminasikan kepada kolega guru lainnya. Metode kegiatan ini \\
& dilaksanakan melalui tiga tahap yaitu persiapan, pelaksanaan, dan evaluasi. \\
Keywords: & Adapun hasil dari kegiatan yaitu berupa empat permainan tradisional modifikasi \\
permainan tradisional, & untuk anak usia Kelompok Bermain (2-4 tahun) meliputi Lingkaran binatang \\
pembelajaran, anak, & (mengembangkan dari permainan tradisional Jamuran), Tanaman keliling \\
karakter & (mengembangkan dari permainan tradisional Cublak-cublak suweng), Sayuran \\
& (mengembangkan dari permainan tradisional Jamuran), dan Lompat rintangan \\
& (mengembangkan dari permainan tradisional lompat tali), serta tiga permainan \\
& tradisional modifikasi untuk anak usia 5-6 tahun meliputi: Menara menari \\
& (mengembangkan dari permainan tradisional Boi-boi an), Bermain sebut nama \\
& (mengembangkan dari permainan tradisional Cublak-cublak suweng), dan \\
& Jamuran jeneng kewan (mengembangkan dari permainan tradisional Jamuran). \\
& Hasil evaluasi menunjukkan bahwa lebih dari 90\% peserta pelatihan \\
& memahami pengembangan modifikasi permainan tradisional untuk \\
& mengembangkan karakter anak usia dini.
\end{tabular}

Traditional games have a variety of benefits for early childhood development, including for shaping the character of early childhood. This training program aims to improve teacher understanding of how to modify traditional games, then use them in learning, and disseminate to other teacher colleagues. The method of this activity is carried out through three stages namely preparation, implementation and evaluation. As for the results of the activities in the form of four traditional game modifications for children of Playgroup (2-4 years) including animal circles (developing from the traditional games Jamuran), Traveling plants (developing from traditional games Cublak-cublak suweng), Vegetables (developing from traditional games Jamuran), and Jump Obstacle (developing from traditional games Lompat tali), as well as three traditional modification games for children aged 5-6 years including Menara menari (developing from traditional games Boi-boian), Play naming (developing from traditional games Cublak-cublak suweng), and Jeneng kewan (developing from the traditional games Jamuran). Evaluation results show that more than $90 \%$ of trainees understand the development of traditional game modifications to develop the character of early childhood.

\section{PENDAHULUAN}

Pendidikan merupakan salah satu cara dari pemerintah untuk meningkatkan kualitas sumber daya manusia. Pemerintahan saat ini telah mencanangkan NAWACITA yang di dalamnya terdapat pembentukan karakter bangsa. Wujud dari penjabaran NAWACITA terutama tentang pengembangan karakter bangsa termaktub dalam Peraturan Presiden (Perpres) Nomor 87 Tahun 2017 tentang pendidikan berkarakter. Pada Bab II pasal 6 disebutkan bahwa penyelenggara pendidikan karakter 
Jurnal Pendidikan Anak, Volume 9 (1), Tahun 2020

Banu Setyo Adi, Sudaryanti, Muthmainnah

dilakukan secara terintegrasi dalam kegiatan intrakurikuler, kokurikuler, dan ekstrakurikuler. Berdasarkan penekanan pada pasal tersebut, maka kegiatan pendidikan karakter dilaksanakan pada seluruh kegiatan sekolah. Adapun lima karakter yang diharapkan oleh pemerintah yaitu nasionalisme, integritas, kemandirian, gotong-royong, dan religius (Republika, 2016.)

Pendidikan Anak Usia Dini merupakan salah satu jenjang pendidikan yang mengakomodir usia 0 sampai 6 tahun. Pada jenjang pendidikan ini terdapat dua jalur yaitu pendidikan formal melalui Taman Kanak-kanak (TK), dan jalur nonformal melalu Kelompok Bermain (KB). Keduanya tidak mempunyai perbedaan dalam proses pendidikannya. Tujuannya yaitu mengembangkan aspek anak yaitu kognitif, bahasa, nilai agama dan moral, fisik motorik, sosial emosional, dan seni. Dalam mencapai tujuannya, lembaga PAUD menyelenggarakan pendidikan yang menggunakan berbagai metode pembelajaran, salah satunya melalui permainan tradisional.

Permainan tradisional merupakan warisan budaya bangsa yang sudah dimainkan sejak dulu. Permainan tradisional mampu menstimulasi berbagai aspek perkembangan anak. Sebagai bagian dari pendidikan, guru sudah semestinya mengenalkan kepada anak tentang permainan tradisional tersebut. Terdapat beberapa macam permainan tradisional mulai dari olah pikir, bernyanyi, dan ketangkasan. Permainan tradisional terbukti sarat dengan makna dan muatan nilai positif untuk mmebentuk karakter anak sebagai generasi penerus bangsa.

Pada kenyataannya, saat ini keberadaan permainan tradisional mulai tergerus oleh perkembangan budaya. Sebagian anak tidak lagi mengenal permainan tersebut, dan disibukkan dengan permainan virtual yang mengakibatkan tubuh menjadi pasif. Sebagian anak hanya diam di rumah untuk memainkan permainan yang ada di smart phone. Budaya tersebut tentunya tidak mendukung program pemerintah terkait pendidikan karakter.

Guru sebagai salah satu ujung tombak pendidikan mempunyai peranan dalam budaya. Peran guru dalam mengenalkan budaya dan nilai-nilai karakter di dalamnya menjadi penting. Namun, fakta yang terjadi adalah guru mengalami keterbatasan kreativitas dalam penyesuaian permainan tradisional dan pemahaman yang terbatas terhadap permaiinan tradisional. Sumber pengetahuan yang diperoleh tentang permainan tradisional hanya sebatas pada pengalaman empirik dari masing-masing guru. Hal tersebut menyebabkan perbedaan persepsi terhadap permainan tradisional. Selain itu, pada dasarnya permainan tradisional dapat dimodifikasi dengan menyesuaikan usia anak, ketersediaan lahan, dan peralatan yang dimiliki. Dengan demikian, program pelatihan ini bertujuan agar para guru mampu memodifikasi permainan tradisional agar dapat dikembangkan melalui pembelajaran dan akhirnya dapat mendiseminasikan kepada kolega guru lainnya.

\section{METODE}

Metode kegiatan yang dilakukan meliputi persiapan, pelaksanaan, dan evaluasi. Persiapan dilakukan dengan analisis kebutuhan guru-guru TK dan menyiapkan berbagai bahan dan materi yang akan disampaikan dan dilakukan saat pelaksanaan. Sedangkan untuk pelaksanaan kegiatan diselenggarakan pada hari Sabtu dan Minggu, tanggal 7-8 September 2019 di TK Aisyiyah Nyai Ahmad Dahlan Kotagede Yogyakarta. Kegiatan ini mengundang semua tenaga pendidik di gugus Ceria Kotagede serta melibatkan mahasiswa. Pemahaman tentang permainan tradisonal (pencapaian tujuan pelatihan) dilakukan dengan pretest dan posttest. Metode yang dipilih untuk mengetahui tercapainya indikator keberhasilan dalam pelaksanaan pelatihan dilakukan dengan dua cara yaitu evaluasi selama proses pelatihan, dan evaluasi pasca pelatihan.

\section{HASIL DAN PEMBAHASAN}

\section{Hasil}

Secara umum kegiatan berjalan sesuai dengan yang direncanakan. Kegiatan pada hari pertama dimulai pada jam 09.00 WIB, yang diawali dengan presensi, dilanjutkan dengan acara pembukaan dan perkenalan antara tim pengabdi dengan peserta pelatihan. Di awal pertemuan, para guru sudah tampak antusias untuk mengikuti kegiatan pelatihan. Pukul 09.30 WIB, acara dilanjutkan 
Jurnal Pendidikan Anak, Volume 9 (1), Tahun 2020

Banu Setyo Adi, Sudaryanti, Muthmainnah

dengan pemaparan materi pertama tentang teori bermain. Pada sesi ini, para guru menceritakan pengalamannya dalam melaksanakan permainan yang pernah diimplementasikan dalam pembelajaran di lembaga masing-masing, baik pada saat proses pembelajaran maupun di luar proses pembelajaran. Para guru di setiap sekolah juga menyatakan bahwa proses penerapan permainan tradisional tidak mudah untuk diimplementasikan. Setelah pemaparan materi tentang teori, maka dilakukan diskusi antara pemateri dengan peserta.

Kegiatan dilanjutkan dengan pemaparan materi kedua pada pukul 10.45 WIB. Pada sesi ini, peserta diberikan pemahaman tentang macam-macam permainan tradisional. Setelah pemaparan materi, maka dilanjutkan dengan sesi tanya jawab. Pada pemaparan materi ke tiga, peserta diajak untuk mencermati kurikulum dan mencoba untuk mencari materi ajar yang bisa untuk penerapan permainan tradisional.

Pada hari kedua, yaitu hari Sabtu tanggal 8 September 2019, kegiatan dilanjutkan kembali. Hari kedua ini dimulai tepat pukul 09.00 WIB, diawali dengan materi Pengembangan pengembangan permainan tradisional dalam pembelajaran dan dilanjutkan dengan pendampingan oleh tim pengabdi untuk mengembangkan permainan tradisional pembelajaran. Pada sesi ini peserta dikondisikan berkelompok sesuai dengan jenjang kelas di sekolah masing- masing. Peserta nampak sangat antusias untuk mengikuti kegiatan karena model pendampingan yang dilakukan oleh tim pengabdi dapat membuat peserta menjadi aktif. Setelah menyusun skenario, maka aktivitas dilanjutkan dengan simulasi dan refleksi.

Bukti ketercapaian target kegiatan pengabdian ini dapat dilihat dari proses dan produk. Proses nampak dari keseriusan, keantusiasan, dan keterlibatan aktif seluruh peserta pelatihan pada setiap sesi kegiatan. Lebih lanjut, produk yang berupa hasil karya peserta yang berupa rancangan permainan tradisional yang akan diterapkan pada pembelajaran di kelas masing-masing.

Permainan tradisional merupakan warisan budaya bangsa yang sarat akan nilai dan dapat digunakan untuk mengembangkan potensi anak, termasuk perkembangan sosial emosional anak. Perkembangan sosial emosional dapat diarahkan pada pembentukan karakter anak, seperti kemandirian, tanggung jawab, percaya diri, empati, taat pada aturan, sportif, jujur, gigih, menghargai orang lain, mampu bekerjasama dan saling membantu. Melalui permainan, secara tidak langsung anak dibiasakan (habituasi) untuk menerapkan nilai-nilai karakter, yang diharapkan akan terinternalisasi dalam diri anak. Selain itu, permainan juga dapat mendorong anak untuk berinteraksi, belajar bersosialisasi dengan lingkungan, serta mengendalikan perasaan.

Adapun permainan tradisional yang dapat diterapkan di TK untuk pengembangan sosial emosional antara lain:

\begin{tabular}{lll}
\hline No & Nama permainan tradisional & Nilai karakter yang dikembangkan \\
\hline 1 & Cublak-cublak suweng & Kesabaran, kejujuran, sportivitas \\
\hline 2 & Engklek & Kegigihan, kemandirian, sportivitas \\
\hline 4 & Kucing-kucingan & Kegigihan, kejujuran, sportivitas, kerjasama \\
\hline 5 & Gobag sodor & Percaya diri, kegigihan, kejujuran, sportivitas, kerjasama \\
\hline 6 & Lompat an & $\begin{array}{l}\text { Kegigihan, kemandirian, kejujuran, sportivitas, percaya } \\
\text { diri }\end{array}$ \\
\hline 7 & Ular naga & $\begin{array}{l}\text { Percaya diri, kegigihan, kemandirian, kejujuran, } \\
\text { sportivitas }\end{array}$ \\
\hline 8 & Dhelikan (petak umpet) & $\begin{array}{l}\text { Kemandirian, tanggung jawab, kerjasama, kegigihan, } \\
\text { kejujuran, sportivitas }\end{array}$ \\
\hline 9 & Egrang bathok & Kegigihan, percaya diri, kejujuran, sportivitas \\
\hline 10 & $\begin{array}{l}\text { Oyak-oyakan/dolip-dolipan } \\
\text { (kejar-kejaran) }\end{array}$ & Kegigihan, kemandirian, percaya diri \\
\hline dan permainan tradisional lainnya & \\
\hline
\end{tabular}


Jurnal Pendidikan Anak, Volume 9 (1), Tahun 2020

Banu Setyo Adi, Sudaryanti, Muthmainnah

Secara rinci, kemampuan sosial emosional yang dapat dikembangkan melalui permainan tradisional antara lain:

1) Menunjukkan sikap mandiri dalam memilih kegiatan

Anak dapat memilih peran apa yang akan dimainkan, misalnya di permainan ular naga, anak dapat memilih peran sebagai pemimpin atau anggota. Secara tidak langsung, anak juga akan belajar tanggung jawab.

2) Mengendalikan perasaan dan menunjukkan empati

Menang kalah adalah suatu hal yang wajar dalam suatu permainan. Melalui permainan, anak dapat belajar mengendalikan perasaan. Saat anak mengalami kemenangan, maka anak perlu mengendalikan diri agar tidak terlalu menunjukkan euforia atau bahkan mengejek teman yang kalah. Sebaliknya saat mengalami kekalahan, maka anak tidak perlu terlalu sedih dan bahkan marah karena masih ada kesempatan untuk bermain di lain kesempatan. Anak dapat dilatih untuk mengeskpresikan emosi sesuai dengan kondisi yang ada secara wajar dan menunjukkan sikap empati pada orang lain.

3) Menunjukkan rasa percaya diri

Percaya diri diperoleh anak saat anak mampu menunjukkan eksistensi diri saat bermain, yaitu bahwa dirinya mampu menyesuaikan diri dan bisa bermain. Saat bermain, anak memperlihatkan kemampuan diri untuk menyesuaikan diri dengan situasi. Bahkan saat anak mengalami kemenangan saat bermain, anak akan semakin percaya pada kemampuan diri dan kelompoknya, meskipun kemenangan bukanlah tujuan utama mengikuti suatu permainan.

4) Memahami peraturan dan disiplin

Dalam permainan tentunya ada aturan misalnya yang kecuit atau kena adalah yang jadi, maka anak perlu memahami aturan dan belajar menaati serta bersikap sportif. Dalam hal ini, guru perlu cermat melakukan pengamatan terhadap anak saat permainan dan memberikan arahan bagi anak yang belum bersikap sportif.

5) Memiliki sikap gigih (tidak mudah menyerah)

Dalam mengikuti permainan tradisional seperti kucing tikus atau ular naga, anak akan mencoba untuk tidak kecuit atau kena, gigih serta bertanggung jawab untuk menjaga yang harus dilindungi. Kalaupun anak "jadi” karena kecuit, maka anak akan gigih untuk nyuit temannya agar dirinya bisa masuk lagi dalam permainan.

6) Menghargai keunggulan orang lain

Saat kelompok lain menunjukkan keunggulan atau kemenangan, maka anak belajar untuk menghargai keungggulan orang lain. Selain itu, anak perlu dibesarkan hatinya agar tetap mau bermain di lain kesempatan dan memiliki keyakinan bahwa dirinya memiliki kemampuan dan bisa menang di lain kesempatan.

7) Mau membantu teman bermain dengan teman sebaya

Dalam permainan tentunya ada kerjasama dimana anak didorong untuk saling membantu mencapai tujuan bersama.

8) Menunjukkan antusiasme dalam melakukan permainan kompetitif secara positif

Anak menunjukkan antusiasme dalam mengikuti permainan bersama teman-temannya, sehingga permainan akan lebih menyenangkan dan anak bebas mengekspresikan emosinya melalui permainan. Selama mengikuti permainan, anak dibiasakan untuk bersikap sportif dalam mengikuti permainan.

\begin{tabular}{llll} 
& & Tabel 1. Contoh kreasi permainan tradisional & \\
\hline No & $\begin{array}{l}\text { Nama permainan } \\
\text { tradisional }\end{array}$ & Kreasi atau variasi & \\
\hline 1 & Engklek & Untuk bentuk dan ukuran menyesuaikan kemampuan anak \\
\hline 2 & Gobag sodor & Gobag bundar simpang tiga & \\
\hline 3 & Boi-boinan & Medianya bisa menggunakan balok & \\
\hline 4 & Lompat tali & $\begin{array}{l}\text { Anak melompat sambil berhitung atau menyebutkan satu benda } \\
\text { terkait tema/sub tema }\end{array}$ & \\
\hline 5 & Egrang bathok & $\begin{array}{l}\text { Bisa dilakukan dengan estafet atau permainan kelompok, } \\
\text { bergantian menggunakan egrang bathok }\end{array}$ & \\
\hline
\end{tabular}


Jurnal Pendidikan Anak, Volume 9 (1), Tahun 2020

Banu Setyo Adi, Sudaryanti, Muthmainnah

Setelah pemaparan materi selesai, maka kegiatan dilanjutkan dengan workshop pengembangan permainan tradisional modifikasi. Adapun dari kegiatan dihasilkan beberapa permainan tradisional modifikasi untuk anak usia Kelompok Bermain (2-4 tahun) yaitu lingkaran binatang (mengembangkan dari permainan tradisional Jamuran), tanaman keliling (mengembangkan dari permainan tradisional Cublak-cublak suweng), sayuran (mengembangkan dari permainan tradisional Jamuran), lompat rintangan (mengembangkan dari permainan tradisional lompat tali). Selanjutnya untuk anak usia 5-6 tahun Menara Menari (mengembangkan dari permainan tradisional Boi-boi an), dan Jamuran Jeneng Kewan (mengembangkan dari permainan tradisional Jamuran).

Evaluasi saat pelaksanaan pelatihan meliputi keterlibatan dan kemampuan peserta pada setiap tahap pelatihan. Pada tahap akhir, peserta diharapkan dapat melakukan kegiatan teknis penyusunan rancangan pembelajaran menggunakan permainan tradisional. Selama proses pelatihan ini, peserta menunjukkan hasil sebagai berikut.

1. Lebih dari $90 \%$ peserta pelatihan memahami pengembangan instrumen penilaian proses pembelajaran. Bukti ketercapaiannya nampak pada sesi tanya jawab di setiap kelompok dengan difasilitasi tim pengabdi.

2. Lebih dari $80 \%$ peserta pelatihan bersedia mengembangkan dan menerapkan permainan tradisional dalam pembelajaran. Bukti ketercapaiannya nampak dari wawancara selama proses pelatihan.

Keberhasilan kegiatan pengabdian masyarakat ini telah dievaluasi berdasarkan taraf penyelesaian materi pelatihan. Tim telah melakukan evaluasi dengan mengamati dan memeriksa rancangan instrumen penilaian prosesn pembelajaran yang dihasilkan para guru saat pelatihan. Kegiatan pelatihan ini dapat berjalan dengan lancar karena adanya beberapa faktor pendukung yaitu sebagai berikut:

1. Kesesuaian kebutuhan peserta pelatihan dengan tema kegiatan yang dipilih tim pengabdi.

2. Dukungan dana yang disediakan pihak kampus sehingga semua kebutuhan peserta pelatihan dapat dicukupi.

3. Sikap kooperatif dari pihak sekolah, mulai dari perencanaan, pelaksanaan, sampai evaluasi kegiatan pelatihan.

Selanjutnya faktor penghambat dalam kegiatan ini hanya sekedar hambatan teknis, yaitu terkait dengan penyesuaian jadwal kegiatan. Hal ini terjadi karena padatnya agenda kegiatan sekolah dan kesibukan tim pengabdi. Namun kendala teknis ini dapat segera diatasi dengan baik. Adapun alternatif solusi yang diambil tim adalah membuat kesepakatan dengan khalayak sasaran untuk melaksanakan kegiatan pelatihan pada hari Sabtu dan Minggu.

\section{Pembahasan}

Permainan tradisional sendiri mencakup permainan yang telah dimainkan sejak jaman nenek moyang. Jenis dan ragam permainan tradisional sendiri sangat bermacam-macam. Setiap daerah mempunyai budaya bermain yang berbeda-beda. Di Jawa khususnya di Yogyakarta juga tidak terbatasi oleh teritorial secara jelas asal permainannya.

Kegiatan ini menghasilkan tujuh permainan tradisional modifikasi untuk anak di Lembaga PAUD. Adapun ragam permainan tradisional modifikasi untuk anak usia Kelompok Bermain (2-4 tahun) yaitu lingkaran binatang (mengembangkan dari permainan tradisional Jamuran), tanaman keliling (mengembangkan dari permainan tradisional Cublak-cublak suweng), sayuran (mengembangkan dari permainan tradisional Jamuran), lompat rintangan (mengembangkan dari permainan tradisional lompat tali). Selanjutnya untuk anak usia 5-6 tahun Menara menari (mengembangkan dari permainan tradisional Boi-boi an), dan Jamuran jeneng kewan (mengembangkan dari permainan tradisional Jamuran). Dalam permainan tersebut terdapat nyanyian, olah pikir atau strategi (bethek-bethekan atau tebak-tebakan), dan tentunya permainan fisik. Permainan tersebut sesuai pendapat Sukirman (2005: p 35) mengkategorikan permainan tradisional daerah istimewa yogyakarta menjadi tiga yaitu: 1) bermain dan bernyanyi; 2) bermain dan oleh pikir; dan 3) bermain dan adu ketangkasan. 
Jurnal Pendidikan Anak, Volume 9 (1), Tahun 2020

Banu Setyo Adi, Sudaryanti, Muthmainnah

Permainan tradisional dapat mengembangkan berbagai aspek motorik kasar anak. Perkembangan keterampilan motorik kasar berlangsung dengan cepat. Anak sudah dapat berjalan mundur, berjalan jinjit, berlari, melempar bola, dan menangkap bola dengan dua tangan. Melalui permainan tradisional, anak berlari, berjalan cepat, dan gerakan lainnya yang dapat mengembangkan kemampuan motorik kasar anak. Pernyataan tersebut sesuai dengan deskripsi kemampuan motorik anak usia dini menurut Dewi, R (2005: p 3) yaitu pada usia 4 sampai 5 tahun, perkembangan kemampuan motorik kasar antara lain: 1) berjalan mundur dengan tumit berjingkat; 2) melompat dengan dua kaki bersama-sama ke muka dan ke belakang, ke samping dengan alat atau tanpa alat; 3) menaiki, menuruni dan berjalan di atas papan titian berlari lurus; 4) berjingkat, angkat tumit; 5) meloncat dengan ketinggian kurang lebih 60-70 cm kedua kaki mendarat bersamaan; dan 6) melempar dan menangkap kantong biji.

Aspek perkembangan lain yang dapat distimulasi melalui permainan tradisional yaitu perkembangan nilai moral dan sosial emosional seperti kejujuran, kemandirian, kegigihan, taat aturan, kerjasama, serta nilai positif lainnya. Kedua perkembangan tersebut erat kaitannya dengan pengembangan karakter. Menurut Megawangi (2003), anak-anak akan tumbuh menjadi pribadi yang berkarakter apabila dapat tumbuh pada lingkungan yang berkarakter, sehingga fitrah setiap anak yang dilahirkan suci dapat berkembang segara optimal. Mengingat lingkungan anak bukan saja lingkungan keluarga yang sifatnya mikro, maka sekolah, masyarakat, media massa, atau komunitas lainnya juga ikut mengambil peran dalam perkembangan karakter anak. Mengembangkan generasi penerus bangsa yang berkarakter baik adalah tanggung jawab bersama, dan salah satu cara yang dapat ditempuh adalah melalui penerapan permainan tradisional di sekolah.

\section{SIMPULAN}

Permainan tradisional terbukti dapat mengembangkan karakter anak seperti kesabaran, kejujuran, sportivitas, disiplin, kegigihan, kemandirian, percaya diri, dan kerjasama. Kegiatan ini bermanfaat bagi guru PAUD. Hal ini diperoleh dari hasil wawancara sekaligus sebagai bagian evaluasi pelaksanaan kegiatan. Berdasarkan pengamatan, pelatihan serupa tampaknya diperlukan untuk khalayak sasaran yang berbeda, dan cakupan wilayah yang lebih luas. Lebih lanjut, kegiatan monitoring pasca pelatihan dilakukan untuk mengetahui bagaimana para guru mempraktikkan permainan tradisional dalam proses pembelajaran di lembaga PAUD masing-masing. Selain itu, hasil evaluasi menunjukkan bahwa lebih dari $90 \%$ peserta pelatihan memahami pengembangan modifikasi permainan tradisional untuk mengembangkan karakter anak usia dini. Adapun produk pengembangan permainan tradisional modifikasi yaitu berupa tujuh permainan yang merupakan hasil workshop, dapat ditindak lanjuti menjadi buku panduan yang diharapkan dapat menginspirasi dan dipraktikkan oleh guru PAUD lainnya.

\section{UCAPAN TERIMA KASIH}

Tim mengucapkan terima kasih kepada berbagai pihak yaitu Fakultas Ilmu Pendidikan yang telah memfasilitasi kegiatan melalui dukungan dana DIPA UNY, tim BPP yang telah memberikan masukan, TK Aisyiyah Nyi Ahmad Dahlan Kotagede yang telah berkenan menjadi mitra penyelenggara, serta lembagalembaga PAUD di Gugus Ceria Kotagede yang sangat membantu proses dari awal sampai selesainya kegiatan ini. 
Jurnal Pendidikan Anak, Volume 9 (1), Tahun 2020

Banu Setyo Adi, Sudaryanti, Muthmainnah

\section{DAFTAR PUSTAKA}

Anonim . Ini 5 nilai pengembangan karakter yang dipriotitaskan

Kemendikbudhttp://republika.co.id/berita/pendidikan/eduaction/16/09/20/ odsubs301-ini-5nilai-pengembangan-karakter-yang-dipriotitaskan- kemendikbud.

Dewi, R. (2005). Berbagai masalah anak taman kanak-kanak. Jakarta: Depdiknas.

https://www.kemdikbud.go.id/main/blog/2017/07/penguatan-pendidikan- karakter-jadi-pintu-masukpembenahan-pendidikan-nasional. Diakses pada tanggal 10 November 2019.

Megawangi, R. (2003). Pendidikan karakter untuk membangun masyarakat madani. IPPK Indonesia Heritage Foundation.

Sukirman D. (2005). Permainan tradisional jawa. Yogyakarta: Kepel Press.

. 2017. Penguatan pendidikan karakter jadi pintu masuk pembenahan pendidikan nasional.

Jakarta

Kemdikbud. 